\title{
Development of an information literate school community: Perceived roles and practices of teacher librarians
}

\author{
M.A.Aisah ${ }^{1}$, A.Abrizah ${ }^{2}$, M.K. Yanti Idaya Aspura ${ }^{2 *}$ and \\ Wan Abd. Kadir Wan Dollah ${ }^{3}$ \\ ${ }^{1}$ Kolej Permata Pintar \\ Universiti Kebangsaan Malaysia, Bangi, Selangor, MALAYSIA \\ ${ }^{2}$ Department of Library \& Information Science, \\ Faculty of Computer Science \& Information Technology, \\ University of Malaya, Kuala Lumpur, MALAYSIA \\ ${ }^{3}$ Faculty of Information Management, \\ University of Technology MARA, Shah Alam, Selangor, MALAYSIA \\ e-mail: aisahmohdazmi@yahoo.com; abrizah@um.edu.my; \\ *yanti@um.edu.my (corresponding author); wkadir@salam.uitm.edu.my
}

\begin{abstract}
The research investigates the perceived roles and practices of teacher librarians in developing an Information Literate School Community (ILSC). The study employs a survey method, which was based on a set of an ILSC benchmarks developed by Henri (1995). A web-based questionnaire was e-mailed to 148 teacher librarians from Malaysian secondary schools in which their School Resource Centers (SRCS) received 4 and 5 stars rating for the year 2015 SRCs evaluation. The result showed that the teacher librarians rated 11 roles as being important, however they acknowledged that they have successful (very much) in executing only one task in their practice that is they "ensure that teachers are efficient library users". Teacher librarians evaluated the information services as very important and at the same time, they thoroughly practiced their roles as the stakeholder in terms of delivering and providing information services to the school community. The finding also revealed that the integration of ICT was recorded as having the highest mean gap between perceived roles and practices. This indicated that although teacher librarians had placed integrating ICT as an important role, there was still a lack of practice. Furthermore, this study has attempted to bridge the apparent divide in the practices of information literacy and the perception of the role in developing an ILSC.
\end{abstract}

Keywords: Information Literate School Community (ILSC); Information Literacy; School Resource Centre (SRC); School Libraries; Teacher Librarians.

\section{INTRODUCTION}

The idea of an Information Literate School Community (ILSC) was introduced by James Henri in 1995, where he articulated a set of benchmarks that could be used to assess schools' progress towards information literacy culture, focusing on the school itself, the principal, the teachers, the teacher librarians and the students (Henri 1995). Henri and Bonanno (1999, p.4) coined the term "information literate school community" to describe an "admittedly fuzzy constellation of factors, attributes, goals and practices necessary to an environment in 
which the focus is on learning, rather than teaching, and developing mastery of the processes of becoming informed". That fuzziness, according to Moore (2002) is due to the complexity of school communities and the evolving nature of information literacy, that cannot be captured completely in a snapshot. As a result, it is likely that schools and individuals at any point in time are more likely to "demonstrate a profile of contextualized strengths and weaknesses, rather than some finite quantum of information literacy" (Moore 2002, p.3). This has implications for development strategies and evaluation at individual student, school and regional levels.

However, the challenge with this "fuzzy" undertaking is that the idea of the ILSC is both a concept and a working model. Henri $(2005$, p. 12) declared that: "A school community that places a high priority (policy, benchmarking, funding, and evaluation) on the pursuit of teacher and student mastery of the processes of becoming informed can be regarded as an information literate school". He reinforced the need to make substantive changes and to adopt a 'learning to learn' paradigm to construct information literate communities where teachers are information literate themselves. This shift in thinking brings with it many changes in practice and has special implications for the role of the teacher librarians and the purpose of information services in schools (Lo et al. 2014).

The issue is no longer a concern about the idea of developing the ILSC but rather it is about the proliferation of meanings that are attributed to them. As more and more people use the concept, its meaning will change and will be adapted to meet particular purposes. It is likely that the concept will be misused because it is misunderstood. The purpose of this paper is therefore, to tease out the meaning that can be attributed to the ILSC among its stakeholders. A major challenge for a school that seeks to become an ILSC is to understand the nature of information and to unlock the complex relationships among data, information and knowledge, as well as to promote and sustain a culture and an architecture that will allow the opportunity for knowledge-building. This process of understanding occurs within a culture that is more comfortable for students, and the effective approach is identified in the end by "the extent to which students are confident and competent learners, able to understand the world of information and willing to use and create information within and beyond their school environment" (Oberg 2001, p. iv).

Although James Henri had already listed a set of benchmarks of an ILSC since 1995, not much is known about the benchmarks in developing an ILSC in Malaysia. In relation to information literacy instruction in Malaysia, the information profession understands it as being embedded in the secondary school curricula (Edzan 2008), and schools adopt different approaches in teaching information literacy (Ismail 2014; Othman et al. 2015; Yu, Abrizah and Sani 2016). Although teacher librarians are at the forefront of successful information literacy instruction in schools, little is known about the role and practices of teacher librarians in developing an ILSC in the context of Malaysia. This was highlighted by (Abrizah 2008) that building an ILSC is complex and the role of the teacher librarian to apply information literacy instruction within a curriculum that has had an information literacy framework imposed upon it cannot be underestimated. It is thought to be important and at the same time, there is a need to study how ILSC is understood and practiced by the teacher librarian in Malaysia. Therefore, this study seeks through to understand the context of developing an ILSC from the perspective of teacher librarians as the person who has advocated information literacy in their respective school. 


\section{LITERATURE REVIEW}

Information literacy can be defined as the ability to find, interpret, use and communicate information from a variety of sources. It is a concept without geographic boundaries. Information literacy programmes have appeared in many countries in formal settings such as in schools and higher education institutions. Across the world, teacher librarians work towards developing students' abilities to effectively find, evaluate, use, and create information. The approach to teaching these lifelong, cumulative skills can be designed in myriad ways throughout the global environment (ACRL 2017). This lifelong learning has also been extensively discussed much in the literature on the need to promote information literacy as an integral part of the education system (Lennox and Walker 1993; Behrens 1994).

The idea of the ILSC belongs to a broad family of concepts such as the 'learning school' (Lincoln 1987) or the 'learning organization' (Senge 2006; Marsick and Watkins 1996) or the 'community learners' (Brown and Strafford 1997) or 'collaborative learning communities' (Cooper and Boyd 1995). The ILSC draws from and meshes with emerging learning theory and provides a sound reason for reconceptualizing and, ultimately, reengineering the places we call school. Abbott and Ryan (1999, p.66) claim that:

"As scientists study the process of learning they are realizing that a constructivist model of learning reflects their best understanding of the brain's natural way of making sense of the world. Constructivism holds that learning is essentially active. A person learning something new brings to that experience all of their previous knowledge and present mental patterns. Each new fact or experience is assimilated into a living web of understanding that already exists in that person's mind. As a result, learning is neither passive nor simply objective"

Cooper and Boyd (1995) mentioned that the ILSC can be viewed as 'a philosophy as well as a place; it is a way of being as well as a working model. It is a mindset as well as a map. Henri (2005) highlighted five focuses of an ILSC i.e. the principal, teacher, teacher librarian, student and the school that could be used to assess a school's progress towards information literacy culturing. However, for the purpose of this review, the scope was specifically narrowed down into one dimension that focuses on the teacher librarian only. In relation to the underlying teacher librarian focuses on developing an ILSC, Henri (1995) has highlighted policy development of ILSC and four domains of roles and practices. The domains are: (a) Information services roles; (b) Learning and assessment roles; (c) Integration of ICT roles and (d) Continuing professional development roles.

As far as information literacy is concerned, from a practical perspective, the teachers' contribution is of importance as they decide on and set activities and tasks (Williams and Wavell, 2006, p. 200). Henri (2001) earlier argued that the key agent in the fight for information literate schools is the teacher. The teacher is at the front line working with students on a day to day basis and influencing student expectation and behaviour. As teaching practice changes from teacher-focused quantitative approaches to student-centred and more qualitative approaches, the importance of the teacher as role model and mentor becomes paramount. According to Scheirer (2000), the role of teacher librarian is significant in order to instill information literacy skills and to promote life-long learning in students. Tan, Gorman and Singh (2012) opined that teacher librarians in Malaysia may need better information literacy skills to provide services and perform their tasks in the school libraries. 
However, Tan, Kiran and Diljit's (2015) study, which gauge school librarians' perception about their readiness in the implementation of information literacy education in Malaysian secondary schools, found that school librarians indicated a low level of technical readiness when asked to self-assess their information literacy skills. This finding aligned with Ismail (2014), teacher librarians in Malaysia believed that information literacy education was important and had the potential to make teaching and learning activities more engaging and fun. However, there were problems in implementing the information literacy education at school. These problems were associated with individual, organizational, social and cultural factors. As a result, the development and progress of information literacy implementation is slower.

\section{OBJECTIVES AND METHOD}

This study uses a quantitative exploratory descriptive research design to identify, analyze, and compare the perceived roles and the current practices of teacher librarians in developing an ILSC. The objectives of the study were twofold: (a) to identify teacher librarians' perceived roles in developing an ILSC; and (b) to examine the practices of teacher librarians in developing an ILSC. In order to address the research objectives, the following research questions were considered:

a) What are the roles that teacher librarians perceived as important in developing an ILSC?

b) To what extent do teacher librarians practice the roles that they perceived as important in developing an ILSC?

This study was conducted in the state of Selangor Malaysia, and the population of the study was 243 teacher librarians from secondary schools in 11 districts of the state. Random sampling was used, and the unit of analysis was teacher librarians from secondary schools that achieved 4 and 5 stars rating in the 2015 school library rating programme (iQ-PSS). iQPSS which denotes the quality index of school libraries has been used as a standard performance measurement indicator for school libraries in Malaysia since July 2009 (Fadzliaton and Kamarulzaman 2010). Consent to conduct the study was obtained from both the Educational Research and Planning Division (EPRD), Ministry of Education (MOE) Malaysia and Selangor Education Department.

The sampling formula by Krejcie and Morgan (1970) requires a sample of about 148 respondents out of the total population to achieve a confidence level of $95 \%$. A web-based survey was chosen as the method for data collection and it was feasible because MOE has provided various online web-based systems for teachers such as Virtual Learning Environment (VLE), 1Bestari.NEt, Human Resource Management Information System (HRMIS), School Analysis Examination System (SAPS) and the iQ-PSS evaluation for teacher librarians. Therefore, by having such experiences in dealing with the online web-based systems, it is expected that teacher librarians can easily respond to the web-based questionnaire disseminated through e-mails.

The web-based questionnaire using Google doc forms was distributed to the sample via emails. The e-mail addresses of were taken from the school directory on the IQ-PSS official website in January 2017. The survey was promoted by the State Educational Resource Centre through informal reminders during meetings and workshops with teacher librarians involved. E-mails were also sent to samples shortly before deadlines. Data collection ended after three months and achieved a response rate of 86.5 percent ( 128 usable questionnaires) 
from 75 (62.5\%) school libraries with 4 stars and 53 (37.5\%) with 5 stars rating. Responses were then collated and analysed. A high response rate was achieved most probably due to the following reasons: (a) more contact with the sample via reminder announcements, emails and text-message prompts (via telephone); and (b) topic interest to members of the target group.

The questionnaire design was based on an adopted and customized ILSC benchmarks developed by Henri (1995). There are 36 item statements of roles and practices underlying teacher librarians focusing on four dimensions: Information Services (10 items), Learning and Assessment (8 items), Integration of ICT (6 items) and Continuing Professional Development (12 items). Each statement has to be answered from two perspectives: (a) belief in importance of the role (using a Likert scale of 5 points - Not important at all; Not important; Somewhat important; Important; Very important) and (b) current practice of the role (using a Likert scale of 5 points - Not at all; Very little; Somewhat; Very much; To great extent). The questionnaire was earlier tested on 15 teacher librarians from another district, of whom reported that they did not encounter any problem in responding to the items.

The perceived importance and the current practices for each item were estimated by using the relative mean, as well as other statistical methods to determine the ranking of different items. The relationship between the perceived importance and the current practice was identified through the mean differences i.e. gap analysis. Gap analysis is a formal means to identify and correct gaps between the desired levels and actual levels of performance in an organization (Lagzian, Abrizah and Wee 2015). It is used in this case to compare the actual practice in establishing an ILSC against its perceived importance in order to determine whether the teacher librarians are meeting expectations and using their resources effectively. This can be done by answering the questions "where are we?" (the current state) and "where do we want to be?" (the desired state). In this study the gap analysis compares two views on the development of an ILSC: "where the ILSC are" (actual practices) and "where the ILSC want to be" (perceived importance). The results allow the teacher librarians to prioritize actions and measure improvement in development of an ILSC.

\section{FINDINGS}

Teacher librarians have a key role in the development of an ILSC, however what are the roles that teacher librarians perceived as important? To what extent do teacher librarians practice their roles in developing an ILSC? The answers to these research questions are presented in Table 1. Statements that received a mean of 4 (important) or 5 (very important) for Perceived Important (Column 4) and a mean of 4 (very much) or 5 (to a great extent) for Current Practices (Column 5) are considered to address the research questions. Teacher librarians perceived the following 11 roles to be important in developing an ILSC (in ranked order):

a) Map the information resources in the school ( $M=4.30)$

b) Ensure that teachers are efficient library users ( $M=4.30)$

c) Ensure that the school has an internet portal $(M=4.20)$

d) Ensure that the school is aware of the educational potential of available information technologies ( $M=4.16)$

e) Make sure that other teachers integrate information technology into all teaching programs.( $M=4.09)$

f) Make sure that information technology needs are prioritized with the allocation of appropriate funding $(\mathrm{M}=4.08)$

g) Map the information resources with the curriculum requirements $(M=4.07)$ 
Asiah, M.A. et al.

h) Identify students' information needs ( $M=4.04)$

i) Ensure that learning using the internet is the dominant consideration in its design and maintenance. (4.03)

j) Make use of the knowledge in librarianship ( $M=4.02)$

k) Emphasizes the process of learning from information-constructing knowledge as the focus of teaching and learning. $(M=4.00)$

On the other hand, the respondents acknowledged that they have successful (very much) in executing only one task in their practice, that is they "ensure that teachers are efficient library users" (M=4.15). The difference between perceived importance and actual performance means was very clear, ranging from 0.01 (Put an effort to maximize patronage of the library through extended opening hours) to 0.57 (Map the information resources in the school). None of the items had a mean difference greater than 1.00. The data provide very strong evidence that, for each variable, importance was rated higher than actual performance (Table 1). This indicates that while the respondents placed a high degree of importance on certain items, the extent of the implementation of those factors differed. The results show the gap between importance and practices of factors, suggesting that although respondents were aware of the important roles those factors could play in establishing an ILSC, they were not able to exert control over all of the factors to a great extent into their practice. "Modelling lifelong learning by testing and trialing information skills strategies", which refers to learning and assessment is a variable over which teacher librarians are likely to have little control, if they are not in the curriculum committee. Similarly, "Making sure that information technology needs are prioritized with the allocation of appropriate funding" and "ensuring that the school is aware of the educational potential of available information technologies", are two cases in point where the teacher librarian is likely to have little control unless he or she is in the school management.

Table 1: Mean Comparison between Perceived Importance and Current Practices in Developing an ILSC (Rank is based on the Gap)

\begin{tabular}{|c|c|c|c|c|c|}
\hline \multirow[t]{2}{*}{ Rank } & \multirow[t]{2}{*}{ Role } & \multirow[t]{2}{*}{ Items } & \multicolumn{3}{|c|}{ Mean } \\
\hline & & & $\begin{array}{l}\text { Perceived } \\
\text { Important* }\end{array}$ & $\begin{array}{c}\text { Current } \\
\text { Practices** }\end{array}$ & Gap \\
\hline 1 & $\begin{array}{l}\text { Information } \\
\text { service }\end{array}$ & Map the information resources in the school. & 4.30 & 3.73 & 0.57 \\
\hline 2 & $\begin{array}{l}\text { Learning \& } \\
\text { assessment }\end{array}$ & $\begin{array}{l}\text { Model lifelong learning by testing and trialing } \\
\text { information skills strategies }\end{array}$ & 3.58 & 3.04 & 0.54 \\
\hline 3 & $\begin{array}{l}\text { Information } \\
\text { technology }\end{array}$ & $\begin{array}{l}\text { Make sure that information technology needs are } \\
\text { prioritized with the allocation of appropriate funding. }\end{array}$ & 4.08 & 3.57 & 0.51 \\
\hline 4 & $\begin{array}{l}\text { Information } \\
\text { technology }\end{array}$ & $\begin{array}{l}\text { Ensure that the school is aware of the educational } \\
\text { potential of available information technologies. }\end{array}$ & 4.16 & 3.67 & 0.49 \\
\hline 5 & $\begin{array}{l}\text { Information } \\
\text { service }\end{array}$ & $\begin{array}{l}\text { Map the information resources with the curriculum } \\
\text { requirements. }\end{array}$ & 4.07 & 3.59 & 0.48 \\
\hline 6 & $\begin{array}{l}\text { Continuing } \\
\text { professional } \\
\text { development }\end{array}$ & Read widely in such area as information education. & 3.75 & 3.30 & 0.45 \\
\hline 7 & $\begin{array}{l}\text { Continuing } \\
\text { professional } \\
\text { development }\end{array}$ & $\begin{array}{l}\text { Participate in the professional development of other } \\
\text { teacher librarians. }\end{array}$ & 3.88 & 3.43 & 0.45 \\
\hline
\end{tabular}


8

Continuing

professional

development

9

Information

technology

10

Information

service

11 Learning \&

assessment

12

Continuing

professional

development

13

Information

technology

$14 \quad$ Continuing

professional

development

15

Information

service

16

Continuing

professional development

17 Information technology

18 Learning \& assessment

19 Information service

$20 \quad$ Continuing professional development

21 Learning \& assessment

Continuing professional development Information technology

24 Information service

Continuing professional development

Continuing professional development

27 Information service

28 Learning \& assessment
Encourage teachers to integrate information technology

skills into their teaching and learning in the classroom.

Ensure that the school has an internet portal.

Provide a significant contributions to the development of whole-school information literacy programs.

Arrange for the demonstration of information

technology sources, services and products.

Ensure that the school has adopted an information technology plan.

Educate teachers on issues such as copyright, privacy, intellectual property rights and freedom of information.

Seek funding from outside school sources to support school-based information literacy initiatives.

Read widely in such area as information technology.

Make sure that other teachers integrate information technology into all teaching programs.

Emphasizes the process of learning from informationconstructing knowledge as the focus of teaching and learning.

Make sure that current information services can be used as resources in supporting the curriculum.

Provide teachers with strategies in implementing the information technology skills.

Encourage discussion about the effect an information policy might have on teaching and learning.

Educate students on issues such as copyright, privacy, intellectual property rights and freedom of information.

Ensure that learning using the internet is the dominant consideration in its design and maintenance.

Develop levels of performance indicators for the

identification of information literacy.

Make use of the knowledge in information technology.

Read widely in such area as educational administration. 
Asiah, M.A. et al.

29

Information

service

30

Continuing professional development

31 Learning \& assessment

32 Learning \& assessment

Continuing professional development

34 Information service

35 Learning \& assessment
Identify skills-based learning goals from curriculum documents.

Make use of the knowledge in librarianship.

Collaborate with teachers to integrate information skills into teaching programs

Reinforce the desirability of student and the use of a metacognitive tool (thinking /learning logs etc).

Ensure that teachers are efficient library users.

Identify students' information needs.

Reinforce the desirability of student self-assessment.

Put an effort to maximize patronage of the library through extended opening hours.

*1= Not important at all; $2=$ Not important; 3=Somewhat Important; 4=Important; 5=Very important

${ }^{* *} 1=$ Not at all; $2=$ Very little; $3=$ Somewhat; $4=$ Very much; $5=$ =To great extent

When the items were analyzed by the dimensions or factors associated to each, findings indicate that integration of information technology factor has the most gap (0.43) between perceived importance and current practice, followed by learning and assessment (0.35), continuing professional development (0.34) and lastly information services (0.33) (Table 2). These findings indicate that teacher librarians perceived ICT role as most important but there was a lack of implementation or less practiced by teacher librarians. From the results, it is evident that small differences of mean comparison for this role revealed that teacher librarians mostly practiced and perceived the information services role as important and most important.

Table 2: Gap between Perceived Important Roles and Current Practices of each Dimension in ILSC Implementation

\begin{tabular}{lcccc}
\hline Dimension & No of items & $\begin{array}{c}\text { Perceived } \\
\text { Importance }\end{array}$ & $\begin{array}{c}\text { Current } \\
\text { Practices }\end{array}$ & Mean Gap \\
\hline \hline Information services & 10 & 3.96 & 3.63 & 0.33 \\
Continuing professional development & 12 & 3.87 & 3.53 & 0.34 \\
Learning and assessment & 8 & 3.77 & 3.42 & 0.35 \\
Integration of ICT & 6 & 4.09 & 3.66 & 0.43 \\
\hline \hline
\end{tabular}

*1= Not important at all; 2=Not important; 3=Somewhat Important; 4=Important; 5=Very important **1=Not at all; 2=Very little; 3=Somewhat; 4=Very much; 5=To great extent

A spider web plot (Figure 1) facilitates comparison of differences or gap between the factors teacher librarians feel as important and the actual performance of this factor in developing an ILSC. Integration of ICT (perceived importance, $M=4.09$, current practices, $M=3.66$ ) was recorded as having the highest mean gap $(M=0.43)$, revealing that although teacher librarians had placed integrating ICT as the most important, they somehow lack of practice in terms of integrating ICT in developing an ILSC. 
On the other hand, findings showed that information services (perceived importance, $M$ $=3.96$, current practices, $M=3.63$ ) has the lowest mean gap $(M=0.33)$. This may indicate that teacher librarians evaluated the information services as important however, not as important as the integration of ICT role. At the same time, they thoroughly practiced this role as the stakeholder in terms of delivering any information services to the school community, especially to the students. Meanwhile means gap for learning and assessment (perceived importance, $M=3.77$, current practices, $M=3.42$ ) is 0.35 and 0.34 for continuing professional development (perceived importance $M=3.87$, current practices $M=3.53$ ).

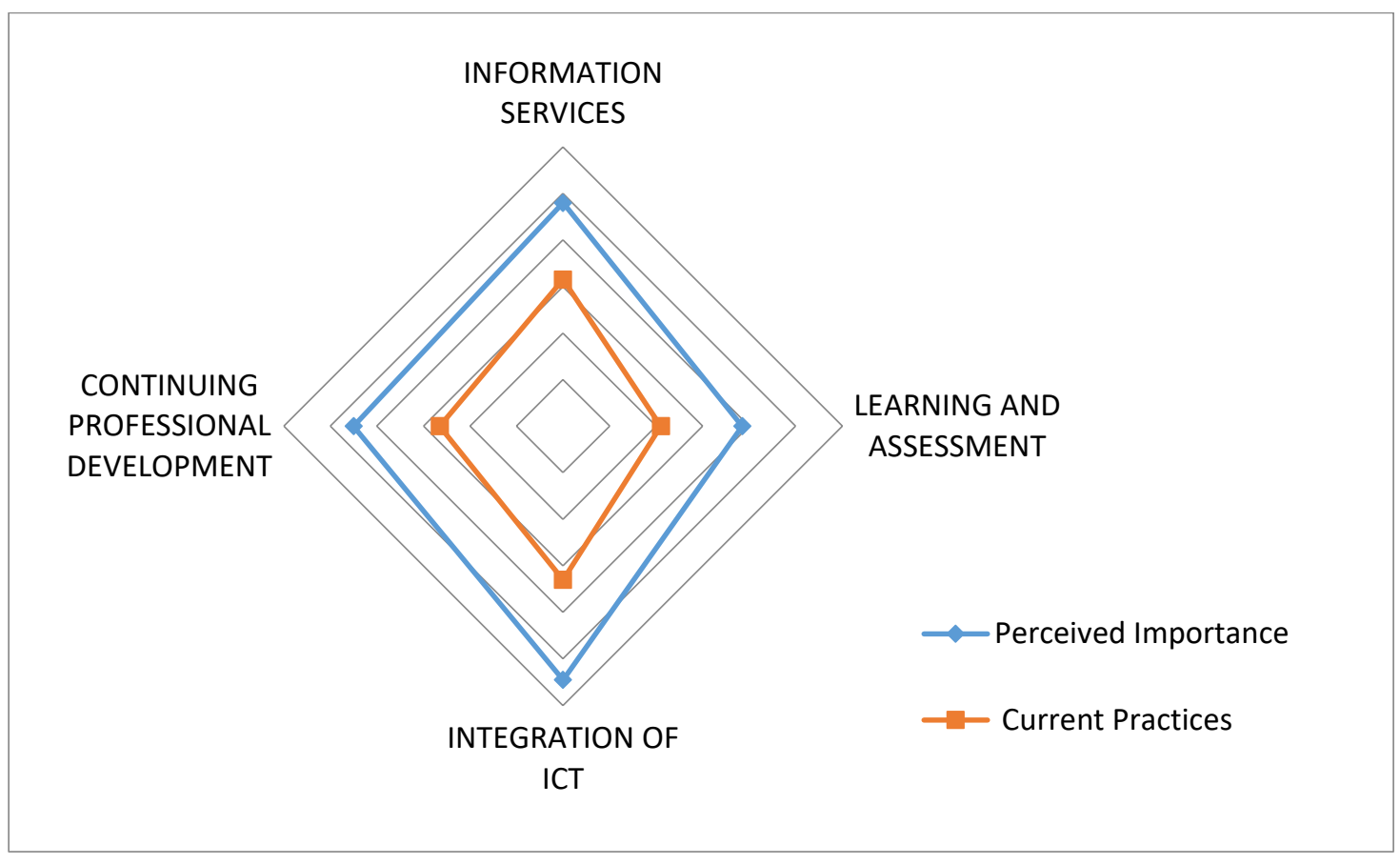

Figure 1: Mean Gap between Important Roles and Current Practices of Teacher Librarian in Developing an ILSC

\section{DISCUSSION}

The findings highlighted that the perceived importance roles in developing an ILSC as outlined in Henri (1995) benchmarks was rated higher than the current practices by the teacher librarians from Malaysian secondary schools whose SRCs received 4 and 5 stars rating for the year 2015 SRCs evaluation. This shows that the teacher librarians were aware of the importance of their roles in Henri (1995) benchmarks. However, they did not fully comply with these recommendations as shown in the lack of practices among them. In addition, the results also showed mixed compliance to the benchmarks as presented through the difference in the gap analysis between perceived importance and current practices for every role item statement.

The gaps identified represent potential areas of improvement in all facets of ILSC implementation. Several factors contribute to the differences between perceived importance and current practice. As an example, the comparison of gap between the perceived importance and the actual practices factors revealed that Integration of ICT (perceived importance: $M=4.09$, current practices: $M=3.66$ ) was recorded as having the 
highest gap $(M=0.43)$. Looking from the Malaysian context, the progression of technology has given a space for teachers to enrich teaching and learning methodology. It is believed that integration of ICT could augment quality of teaching and make learning very effective. However, teacher librarians might not have enough time to learn how to use latest technology due to their workload as stated by Hassan and Kamisan (2010) and Razak and Awaluddin (2006) in their studies. The negative impact of this situation is the teachers do not use technology in the classroom. This statement is supported by Che (2000) saying that even though teachers' attitudes towards the use of technology are positive, their skills in using ICT are still moderate. This is, to some extent, contributed by the teachers' heavy workload. On the other hand, the teacher librarians are still lacking in terms of knowledge on using the websites as a social media to communicate or to convey information to their students as supported by Razak et al. (2014) in their research. In addition, teacher librarians have limited access and knowledge in finding information using website as they are not emphasized on using the web in teaching and learning process.

The other factors that contribute to the gaps differences are the ability to control the task. Although teacher librarians were aware of the important roles those factors could play in establishing an ILSC, they were not able to exert control over all of the factors to a great extent into their practice. For example "Making sure that information technology needs are prioritized with the allocation of appropriate funding" and "ensuring that the school is aware of the educational potential of available information technologies", are two cases in which a teacher librarian is likely to have little control unless he or she is in the school management.

The study demonstrated that teacher librarians generally encourage their students to come to the library to get information, and this role disputes the inspiration of the Ministry of Education to integrate ICT with information literacy. Teacher librarians are supposed to support IL by teaching students how to use the available technology. The common approach in many schools concerns the role of libraries, which are providing more services through the Internet. In addition, most of the school libraries in Malaysia do not provide electronic resources to the patrons. They still use the manual library service due to budget constraint and expertise. As an evident, the role of "put an effort to maximize patronage of the library through extended opening hours" received lowest mean gap 0.01; meanwhile "put an effort to maximize patronage of the library through electronic resources" received 0.43 mean gaps.

A limitation of this study is that it was confined to only teacher librarians from one state in Malaysia, which affected the ability to generalize the findings. Nevertheless, the participating teacher librarians and their school library's characteristics, such as curriculum and teacher-to-student ratio, were similar to those of any local secondary schools of average academic standing. Despite its limitations, the current study is the first empirical study that reported on the roles teacher librarians could play in establishing an ILSC. The small differences of mean comparison for the roles revealed that teacher librarians mostly practiced and perceived the information services role as important and most important. This is evident as the analysis of teacher librarians' perceived importance and current practice were generally aligned.

\section{CONCLUSION}

This study assesses teacher librarians' perceived importance and actual practices role in developing of an information literate school community (ILSC) in accordance to Henri (1995) benchmarks. The finding is useful to the school leaders and teacher librarians to improve 
their weakness in developing an ILSC. Unveiling gaps between teacher librarians' perceived importance and actual practices is beneficial to identify areas that need improvement.

Teacher librarians have a key role in the development of information literacy. School leaders are encouraged to support teacher librarians to develop a clear role statement, reflecting the dual role of both teacher and information specialist. The teacher librarian's flexibility and positive response to change directly influences the success of information literacy programs. The role statement can be adapted to suit the level of responsibility of the teacher librarian. When fulfilling all aspects of the role, the qualified teacher librarian is operating at a leadership level.

There are some recommendations that can be made based on the discussion of the findings. By doing so, it is hoped that it could enhance teacher librarians understanding on the policy for the development of ILSC. As well as the importance and their actual practices of their roles and practices in developing an ILSC. It is recommended that this study could be a baseline for discussion between professional colleagues, decision-makers and teacher librarians on the roles and practices of the latter. The instrument could be used as a checklist to evaluate the implementation of ILSC in Malaysia. It is also suggested that the Ministry of Education should establish a guideline of requirement that will serve all school in Malaysia in order to develop an ILSC. Teacher training colleges or educational institutions that prepare teachers to be teacher librarians should review their program content to ensure that all essential criteria are included. Further study could apply the data derived from the findings of this study as a guideline to investigate any other relevant benchmarks from any other expertise other than Henri (1995). So that a comparison can be made and new ideas can be generated from the research findings.

\section{ACKNOWLEDGEMENT}

This research received no specific grant from any funding agency in the public, commercial, or not-for profit sectors. There are no conflicts of interest involving either of the authors of this paper. The authors thank the teacher librarians whose participants made this study possible.

\section{REFERENCES}

Abbott, J. and Ryan, T. 1999. Constructing knowledge, reconstructing, schooling. Educational Leadership, Vol. 57, no. 3: 66-69.

Abrizah, A. 2008. Building an information literate school community: Approaches to inculcate information literacy in secondary school students. Journal of Information Literacy, Vol. 2, no. 2: 32-45. Available at: https://doi.org/10.11645/2.2.152.

Association of College and Research Libraries (ACRL). 2017. Working Group on Global Perspectives for Information Literacy, Student Learning and Information Literacy Committee. Global Perspectives on Information Literacy: Fostering a Dialogue for International Understanding. Chicago, IL: Association of College and Research Libraries. Available at: http://www.acrl.lib guides.com/slilc/home.

Behrens, S.J. 1994. A conceptual analysis and historical overview of IL. College and Research Libraries, Vol. 55, no. 4: 309-322. 
Brown, G. and Strafford, E. 1997. The feasibility of expanding the assessment resource banks to incorporate English. Unpublished Report. Wellington: New Zealand Council for Education Research.

Che, K.I. 2000. Kemahiran dan sikap pensyarah pendidikan Islam terhadap penggunaan komputer dalam pengajaran di Maktab Perguruan Islam Bangi. Projek Sarjana Pendidikan. Fakulti Pendidikan. Universiti Kebangsaan Malaysia.

Cooper, C. and Boyd, J. 1995. Schools as collaborative learning communities. Available at: http://www.vision.net.au/ globallearning/pages/lfs/clc_artcle.html

Edzan, N.N. 2008. Information literacy development in Malaysia: A review. International Journal of Libraries and Information Services (Libri), Vol. 58, no. 4: 265-280.

Fadzliaton Z. and Kamarulzaman I. 2010. Measuring Malaysia school resource centers' standards through IQ-PSS: an online management information system. International Association of School Librarianship. Available at: http://files.eric.ed.gov/fulltext/ ED518590.pdf

Hassan, J. and Kamisan, S.N. 2010. Halangan terhadap penggunaan komputer dan ICT di dalam pengajaran dan pembelajaran (P\&P) di kalangan guru di sekolah menengah kebangsaan luar bandar di daerah Kulai Jaya, Johor. N/A: 1-10. Unpublished. Available at: http://eprints.utm.my/id/eprint/11032/1/Halangan_Terhadap_Penggunaan_ Komputer_Dan_Ict_Di_Dalam_Pengajaran_Dan_Pembelajaran.pdf

Henri, J. 1995. The information literate school community: exploring a fuzzy concept. Scan, Vol. 14, no. 3: 25-28.

Henri, J. and Bonanno, K. 1999. Centre for Information Studies. The information literate school community: best practice. Centre for Information Studies, Charles Sturt University, Wagga Wagga, N.S.W.

Henri, J. 2005. Understanding the information literate school community. In Henri, J \& Asselin, M. (eds.) The Information Literate School Community 2: Issues of leadership. Charles Sturt University: New South Wales, Australia.

Henri, J. 2001. Thinking and informing: A reality-check on class teachers and teacher librarians. Paper presented at the 30th Annual Conference of the International Association of School Librarianship and the Fifth International Forum on Research in School Librarianship. Seattle, WA.

Ismail, S.A. 2014. Factors affecting the implementation of information literacy education in Malaysian primary schools. Unpublished Dissertation, Victoria University of Wellington.

Krejcie, R.V. and Morgan, D.W. 1970. Determining sample size for research activities. Educational and Psychological Measurement, Vol. 30: 607-610.

Lagzian, F., Abrizah, A. and Wee, M.C. 2015. Measuring the gap between perceived importance and actual performance of institutional repositories. Library \& Information Science Research, Vol. 37, no. 2: 147-155.

Lincoln, P. 1987. The learning school. Boston Spa, UK: British Library.

Lennox, M.F. and Walker, M.L. 1993. IL in the educational process. Educational Forum, Vol. 57, no. 3: 312-324.

Lo, P., Chen, C.C., Dukic Z., Youn, Y.R., Hirakue, Y., Nakahima, M. and Yang, G. H. 2014. The roles of the school librarians as information literacy specialists. New Library World, Vol.115, no. 7/8: 314-339. Available at: https://doi.org/10.1108/NLW-01-2014-0012.

Marsick, V. and Watkins K. 1996. Adult educators and the challenge of the learning organization. Adult Learning, Vol. 7, No. 4: 18-20. Available at: https://doi.org/10.1177/104515959600700409.

Moore, P. 2002. An analysis of information literacy education worldwide. White Paper prepared for UNESCO, the U.S. National Commission on Libraries and Information 
Science, and the National Forum on Information Literacy, for use at the Information Literacy Meeting of Experts, July 2002, Prague, The Czech Republic.

Oberg, D. 2001. Editorial: Perspectives on information literacy. School Libraries Worldwide, Vol. 7, no. 1: i-v.

Othman, N.A., Yaacob, R.A., Bunawan, A.P. A. and Salleh, M. I. 2015. Teachers' information literacy levels in one cluster school in Malaysia, Journal of Information \& Knowledge Management, Vol. 5, no.1: 13-28.

Razak, K.A. and Awaludin, S. 2006. Amalan Pengajaran Guru Pendidikan Islam: Penilaian Kendiri Guru Pendidikan Islam. Seminar Amalan Pengajaran Guru Pendidikan Islam. Fakulti Pendidikan UKM, Bangi.

Razak, K.A., Othman, T.N., Hamzah, M.I. and Zulkifli, H. 2014. Information and communication technology among excellent Islamic education teachers in Selangor Malaysia. International Education Studies, Vol. 7, no. 13: 146-156.

Scheirer, B. 2000. The changing role of the teacher-librarian in the twenty-first century. Canada: University of Saskatchewan. Available at: http://www.usask.ca/education/coursework/802papers/scheirer.htm

Senge, P.M. 2006. The Fifth Discipline - The Art and Practice of the Learning Organization. Random House Digital, Inc. Available at: http://10.1016/0024-6301(95)90931-1.

Tan, S.M., Gorman, G. and Diljit, S. 2012. Information literacy competencies among school librarians in Malaysia. Libri, Vol. 62, no.1: 98-107

Tan, S.M., Kiran, K. and Diljit, S. 2015. Examining school librarians' readiness for information literacy education implementation. Malaysian Journal of Library \& Information Science, Vol. 20, no. 1: 79-97.

Williams, D.A. and Wavell, C. 2006. Information Literacy in the classroom: Secondary school teachers' conceptions. Aberdeen: The Robert Gordon University

Yu, H., Abrizah, A. and Sani, M.K.J.A. 2016. Information literacy through resource-based learning: Malaysian teachers' conception and instructional practices. Malaysian Journal of Library \& Information Science, Vol. 21, no.1: 53-67. 